\title{
Dating the Cooloola coastal dunes of South-Eastern Queensland,
}

\author{
Australia \\ Joe Walker ${ }^{1}$, Brian Lees ${ }^{2} *$, Jon Olley ${ }^{3}$ and Cliff Thompson ${ }^{1}$ \\ 1 ,CSIRO Land and Water, PO Box 1666, Canberra ACT \\ 2611, Australia. \\ 2. University of New South Wales: Canberra, ACT 2610, Australia \\ 3. Australian Rivers Institute, Nathan Campus, Griffith University, Nathan, Qld 4111, \\ Australia
}

\begin{abstract}
The Cooloola sand dunes are part of a series of aeolian parabolic dunes that stretch along the east coast of Australia. They form a chronosequence showing increasing weathering, soil formation and water erosion across six geomorphically recognized soil landscapes. These landscapes were recognized from air photographs and further refined on the basis of some 150 auger holes across the dunes. Data about the structure and floristics of the vegetation were collected at the same time. There is a significant body of literature about the Cooloola dunes but there are two areas that have not been satisfactorily considered. First the previous dating which gave inconsistent results has been superseded by single grain OSL dates and second Cooloola has not been considered in a regional context. Here we report the results of single grain optically stimulated luminescence (OSL) analyses for 31 samples for 21 sites across the geomorphic landscapes. The sites were selected near the apex of each dune as this represents the last depositional date and the least disturbed by sand movement.
\end{abstract}


We recognized 10 units across the dunes on the basis of the dates available. The dune ages ranged from recent to $725 \mathrm{ka}$. The largest dunes at some $320 \mathrm{~m}$ high were dated at around 140 ka. and these dunes carry the maximum vegetation biomass of this dunefield. Beyond this vegetation maximum the dunes had lost their parabolic shape due to prolonged weathering and erosion and the vegetation is greatly reduced in height and biomass. The depth to the soil B horizon gradually deepens with age to form giant podzols in the older dunes. The depth to the B horizon was remarkably consistent within the geomorphic landscapes across the length and breadth of the dunes.

These studies place the Cooloola dunes in a unique position as the chronosequence is intact. The possible processes that lead to the formation of the dunes and the regional implications are discussed. Secondly, it shows the buildup and decline of the dune ecosystems and acts as a model for all ecosystems. Forest succession models which place less emphasis on soil development miss this important process.

Keywords: Cooloola; Coastal Dunes; Quaternary Geomorphology; Inner Shelf Processes; South-West Pacific.

\section{Introduction}

\subsection{Aim}

The aim of this paper is to present our recently completed dating of the Cooloola coastal dune chronosequence, the possible processes which led to the parabolic dune emplacement, and the implications for ecosystem succession and decline. Walker and Thomson, and their co- 
researchers, have published a number of papers on this area. From the substantial series of studies in landscape dynamics by CSIRO Division of Soils (Thompson and Moore, 1984; Ross et al., 1984; Bridge et al., 1985; Reeve et al., 1985) there has flowed an important stream of publications. Thomson's initial papers on the podzol chronosequences which developed through weathering of these large parabolic dune systems (Thomson, 1981; 1983; 1992) were paralleled by investigations of the soil-vegetation interactions (Walker et al., 1981; 1983; 1987); Thomson and Walker, 1987; Harold et al., 1987; Pelzer et al., 2010). In these publications the podzol chronosequence ages were inferred by comparison of the sequence with the Port Stephens-Myall Lakes dune field deposits (Thom, 1965; Thom et al., 1981a; 1981b). It is only recently that extensive dating for the Cooloola chronosequence has been finalized and this we report here. The improved dating using single-grain Optically Stimulated Luminescence (OSL) reveals a more complex history than previously considered.

\subsection{Cooloola}

The Cooloola dune field lies on the eastern Australian coast just north of the Queensland-New South Wales border at about $26^{\circ} 00^{\prime} \mathrm{S}, 153^{\circ} 10^{\prime} \mathrm{E}$ (Fig 1). It is part of the Great Sandy Region National Park. To the immediate north is the large sand mass of Fraser Island, to the immediate south are the Peregian sandhills. Further south are the sand masses of Moreton and the Stradbroke Islands. Fraser Island, Cooloola, Peregian, Bribie, Moreton, North and South Stradbroke Islands are all subaerial fragments of a large sand mass which lies at the north eastern extremity of an inner shelf sand transport system which brought 
sediment north along the coast from as far south as eastern Victoria, possibly even Tasmania, during periods of lower sea levels (Figure 1) (Roy and Thom, 1981; Boyd et al., 2004a;

2004b, Sircombe, 1999). At present sea level, this alongshore transport system is still operating for sections of the northern New South Wales and southern Queensland coasts. At Fraser Island the orientation of the Australian coastline changes and trends northwest. Fraser Island itself extends the northeasterly trend while the mainland shore trends away to the northwest. This brings the northern end of Fraser Island close to the edge of the continental shelf. Just past the northern tip of the island relatively strong inner-shelf currents move the sand offshore and over the shelf edge (Marshall, 1977; Roy and Thom, 1981; Sircombe, 1999; Boyd et al., 2004a; 2004b).

Figure 1: General location of Cooloola on the east coast of Australia. The direction of sediment transport is indicated by the grey arrow.

Parabolic dunes commonly form where areas of bare sand are mobilized by the prevailing winds invade existing vegetated lands, especially those carrying woodlands and forests. Their characteristic $\mathrm{U}$ or $\mathrm{V}$ shape open to the formative wind is due to interactions between wind, bare sand and vegetation in which vegetation along the flanks of the advancing bare sand traps and immobilises some of it, thereby building characteristic long ridges (the trailing arms) that extend upwind on either side of the mobile bare sand (Hesp and Walker, 2013; Yan and Baas, 2015). The parabolic dunes along the subtropical coast of Queensland may be initiated as blowouts in areas of weak or disturbed vegetation on stabilised dunes or by sand from the beach blown inland by onshore winds (Pye, 1982; 1983). It is also quite common to see transgressive dunefields transform into parabolics as they move closer to being stabilized (Hesp, 2013). In either case, large advances downwind are fueled by deflation of the 
underlying formerly anchored dunes. Sieve analyses of the dune sands show that the modal grain size is $212-250 \mu \mathrm{m}$ and that $<1 \%$ are finer than $75 \mu \mathrm{m}$ or coarser than $500 \mu \mathrm{m}$ (Bridge et al., 1985), i.e. they are virtually of ideal size to move by saltation when wind speeds at ground level exceed about $18 \mathrm{~km} / \mathrm{hr}^{-1}$ (see Bagnold, 1949). The development of transient transverse dune forms in the bare mobile sands on the parabolic dune floors also implies that saltation is the main process moving sand downwind.

Stabilisation of the parabolic dunes begins at or near their point of initiation when inputs of sand decline or cease and proceeds downwind along the dune floor and the adjacent trailing arms. This plant colonisation zone is where there is a struggle between plants and wind for control of the bare sand, with plant cover advancing during relatively more benign years and retreating during adverse periods. It is obvious, from partly vegetated parabolic dunes and from differences in the degree of water erosion over the length of stabilised (vegetated) dunes, that the last part to become stabilised is that area furthest downwind (inland), i.e. the apex and closely adjacent trailing arms. The trailing arms tended to be static. As a result, parabolic dunes along the subtropical coast appear to be elongated age structures in which the inland apices are younger and much less degraded by water than remnants of the same dune near the coast. Rates of transgression are therefore difficult to estimate given this episodic nature of movement. Unpublished measurements on a time-series of air photos of the Kurnell Peninsula (Fig 1) by one of us (BGL) show that the average speed of the leading edge of mobile parabolic dunes there was $9 \mathrm{~m} /$ year. Muckersie and Shepherd (1995) reviewed measured and calculated rates of dune migration from a number of studies and found an average rate of $5 \mathrm{~m} /$ year. The rates range from a high of $17 \mathrm{~m} /$ year to a low of $0.05 \mathrm{~m} /$ year. 
Because our research interests were mainly in the interaction between soil profile (podzol) development and changes in vegetation type over time, we needed to know how long a dune had been stabilised by vegetation. Therefore the trailing arm crests adjacent to the apices should provide the most useful sites for our purposes because there is a much lower risk of their having been reworked by the wind during what can be a relatively long period of stability. Reworking by wind erosion can presumably operate over relatively long time periods. Also, because they are usually the higher sites locally, the risk of a substantial overlay of sand from water erosion is negligible. The likelihood of sampling remnants of truncated older dunes is low and can usually be assessed by observation and by drilling with a sand auger. However, while the risks of contamination due to geomorphic processes can be reduced by careful site selection it can do little to reduce the risks of past disturbances due to human activity, especially forestry operations, and bioturbation from native fauna. These can be reduced by avoidance of obviously disturbed areas, increased sampling depth and by replication.

The present climate at Cooloola is sub-tropical. At this latitude, the area is affected by both temperate and tropical weather systems. Dominant winds during January to May are the south-east trades, during April to August southerlies predominate and, during September to December, north to north-easterlies are important (Coaldrake, 1962). The area receives rain throughout the year with a mean annual rainfall of $1500 \mathrm{~mm}$. The wettest months are January to March with calculated evaporation exceeding precipitation from late winter (July) to early summer (November) (Thompson, 1983). The elongate parabolic dunes evident at Cooloola are aligned with the dominant south-east trade winds. 
Geomorphological mapping of the sand masses in the Great Sandy region implies, very strongly, that most have a similar emplacement history. At lower sea levels the extensive sand deposits on the inner shelf have become mobilized and moved onshore (Pye, 1984; Lees, 2006). At least six dune emplacements were recognised in these deposits (Ward, 1977; Thompson, 1981; Thompson and Moore, 1984) and, particularly at Cooloola, these form an almost classic sequence of onlapping units. They form a chronosequence showing increasing weathering, soil formation and water erosion across six geomorphically recognized soil landscapes. These landscapes were recognized from air photographs and further refined on the basis of some 150 auger holes across the dunes and the structure and floristics of the vegetation. These units, shown in figure 2, are also shown as DS 1 to 7(6a) in Figure 4b.

This apparent lack of stratigraphic confusion, and the large number of phases of dune emplacement, makes the Cooloola dune field particularly useful for identifying significant phases of dune deposition and potentially links to the processes responsible. In the case of the CSIRO studies, it presented a unique opportunity to examine soil profile development through time.

An investigation on nearby Moreton Island by Brooke at al., (2015) indicates that it is an exception to this model of an extensive series of onlapping strata but the source of the sediments remains the same. Brooke et al., (2015) identified older units on Moreton Island which dated to about $540 \mathrm{ka}$, about $350 \mathrm{ka}$ and about $96 \mathrm{ka}$. Younger units dated to about 5.7 ka, about $1.3 \mathrm{ka}$, about $0.9 \mathrm{ka}$ and younger than $0.4 \mathrm{ka}$ were also identified. Much of the sand in the Moreton Island deposits has been deeply weathered on the exposed shelf before being delivered to the dune fields during intermediate sea levels (Brooke et al., 2015). Brooke et al., 
(2015) argue that, from their examination of Moreton Island that the onshore transport of exposed inner shelf sands was most likely to be greatest during the prolonged periods that sea level sat at intermediate levels, -20 to $-70 \mathrm{~m}$ below its present level.

Other studies in the area include reconnaissance work by Gontz et al., $(2014 ; 2016)$ looking at the stratigraphy of parts of North Stradbroke Island (Gontz et al., 2014) and Fraser Island (Gontz et al., 2016). Their work at both sites avoided the high dunes and concentrated on providing information on sea-level fluctuations. They identified a variable thickness of aeolian sand over mid-Holocene to present beach deposits overlying an older system. No dates were reported. They report that they also acquired a series of high-resolution reconnaissance-level Ground Penetrating Radar (GPR) lines on the northern end of the Cooloola Sand Mass, but these have not yet been published. Although we identify the present surface morphology at Cooloola as being mainly due to transgressing elongate parabolic dunes, it is entirely possible that the older, more degraded, dunes are a transgressive dune sheet. The forthcoming GPR work may help clarify this.

Others who have worked in the region include Levin et al., (2014) who looked at the relationship between the wind regime on Moreton Island and the dunes. Ward (2006) inferred a chronology of dune emplacement in the Great Sandy Region based on climatic interpretation of ice core data. A more useful summary of more recent regional palaeoclimates is presented by Petherick et al., (2013). Literature for coastal dune field evolution in south east Queensland has recently been reviewed by Miot da Silva and Shulmeister (2016), which is discussed later. 
The Cooloola dunes are massive, reaching some $320 \mathrm{~m}$ in height and stretching over an area of $45 \mathrm{~km}$ by10 $\mathrm{km}$. Some, a minor component, has originated from the erosion of recent volcanic activity in northern NSW and southern Queensland and has been less deeply weathered. The resulting suite of sediments has been described by Thompson (1983). The sediments are mostly quartz with less than $2 \%$ of heavy minerals, ilmenite, rutile, zircon, monzanite and feldspar (Thompson, 1983). There is little or no carbonate material. The different lengths of time the dunes have been exposed to subaerial weathering has resulted in a chronosequence of dune podzolics. The interaction of the weathering process, vegetation and soil biota has been the focus of a number of important papers and will not be revisited here (Thomson, 1981; 1983; 1992; Walker et al., 1981; 1983; 1987; 1999; Thomson and Walker, 1987).

\subsection{Previous Dating}

Samples for a reconnaissance thermo-luminescence dating of the Cooloola dunes were collected in 1987 and 1988 from sites selected for a study of mineral weathering over time along the dune sequence (DS) (Tejan-Kella et al., 1990). The purpose was to establish some absolute ages for at least some stages of the relative age sequence of dune stabilisation and podzol soil development evidenced from field data. No standard depth or soil horizon was nominated for sampling; the samples were collected by sand auger and rapidly transferred to tin containers in dense shade within a hide constructed for the purpose. Subsequently, in situ radiation measurements were made at the sampling depths at each site (by J.R. Prescott pers.com; Prescott and Hutton, 1994). 
Tejan-Kella et al., (1990) found that the Kings Bore sample (DS2) date of $19 \pm 2 \mathrm{ka}$. was completely at variance with its geomorphological relationships, which suggested a much younger age. They were not confident about the DS3 date of $90 \pm 10 \mathrm{ka}$ but much more confident about their DS6 age of $730 \pm 70 \mathrm{ka}$. This latter date is used in later discussion.

The second group of samples for luminescence dating of the dune chronosequence at Cooloola were collected during November 1995 from sites mostly selected to provide a comparison of paired sites, one from a dune crest just above and one from the dune just below the geomorphic contact between two dune systems. Also, three of these sites, one each of Dune Systems 2, 3 and 4 were duplicated on nearby dunes of believed equivalence in age (based on field data) to increase confidence in the luminescence ages determined.

Laboratory techniques have advanced considerably since the methods used in TL1 (TejanKella et al., 1990), and the development of Optically Stimulated Luminescence (OSL) methods provides a more reliable assessment of the duration of burial of quartz sediments since their last exposure to sunlight than earlier luminescence techniques.

\section{Dune sampling and dating}

Unlike many of the northern Australian dune fields which have been dated (Pye and Switsur, 1981; Lees et al., 1990; Lees and Lu, 1991; 1992; Lees et al., 1992; Shulmeister and Lees, 1992; Lees et al., 1993; Lees et al., 1995), the Cooloola dune field is largely stable and vegetated and exposed erosional faces where the stratigraphy and soil horizonation can be examined are rare. In dune podzolics this is an important consideration as the highly mobile A horizon can be transported away to cap a B horizon of different age. In order to avoid 
problems where the apparent upper horizon is in fact a younger deposit, samples were collected from auger holes at two depths where possible. An upper sample was usually collected at $2.5 \mathrm{~m}$ depth, and a lower sample was collected at $3.5 \mathrm{~m}$ depth. All of the sample locations were chosen to identify the inland extent of each of Thompson's inferred soil landscape units (see Figure 2). In order to do this, the location of sampling was at the dune apex or upper crests of trailing arms, hence the youngest part of the stabilized dunes.

At twenty-one locations (Figure 2; Appendix A) a total of 32 samples were collected and are shown in Figure 2. Samples were collected in November 1995 (TL2), September 2001 (TL3) and September 2002 (TL4). The results of initial processing by multiple aliquot OSL methods were published as a pers comm., by Lees (2006) and are superseded by the single grain optically stimulated luminescence (OSL) results published here.

\subsection{Single grain optical dating of the Cooloola Dune samples}

When hidden from light buried quartz grains begin to accumulate a trapped-charge population that increases in a measurable and predictable way in response to the ionising radiation dose to which the grains are exposed. The latter is due to the nuclear decay of the naturally occurring radioactive elements $\left({ }^{238} \mathrm{U},{ }^{235} \mathrm{U},{ }^{232} \mathrm{Th}\right.$, their daughter products, and $\left.{ }^{40} \mathrm{~K}\right)$ in the sample and surrounding material, and to cosmic rays. Exposure to sunlight resets the optically stimulated luminescence signal; a process referred to as 'bleaching'. The time elapsed since sediment grains were last exposed to sunlight may be estimated by measuring the luminescence signal from a sample, determining the equivalent dose $\left(D_{e}\right)$ that this represents (for which the SI unit is the Gray, Gy) and estimating the rate of exposure of the grains to ionising radiation averaged over the period it has been hidden from light (the dose rate $\mathrm{D}_{\mathrm{r}}$; SI units Gy $\mathrm{yr}^{-1}$ ). For grains that were well bleached at the time of deposition the age of burial may be obtained from the following equation:

Burial age $=D_{\mathrm{e}} / \mathrm{D}_{\mathrm{r}}$

Incomplete or non-uniform bleaching of the OSL signal is commonplace in many depositional environments (Olley et al., 2004). For such samples, the population of grains with the lowest measured $D_{e}$ values provides the most accurate estimate of $D_{b}$ : the burial dose 
to which the grains have been exposed since being buried. Olley et al., (1999; 2004) found that for incomplete, or non-uniformly bleached sediments the probability of an optical date exceeding the true age of burial increases with the number of grains measured at a time. They recommended that single grains be measure to enable incomplete or non-uniform bleaching to be identified, and the population of grains with the lowest measured $D_{e}$ values to be determined.

\subsubsection{Sample preparation}

Sample preparation was designed to isolate pure extracts of $180-212 \mu \mathrm{m}$ light safe quartz grains following standard procedures (Aitken, 1998). Treatments were applied to remove contaminant carbonates, feldspars, organics, heavy minerals and acid soluble fluorides. The outer $\sim 10 \mu \mathrm{m}$ alpha-irradiated rind of each grain was removed by etching in $48 \%$ Hydrofluoric Acid. For each site measure 200 to 500 grains were tested.

\subsubsection{OSL analytical methods}

A burial dose was determined from measurement of the OSL signals emitted by single grains of quartz. The etched quartz grains were loaded onto custom-made aluminum discs drilled with a $10 \times 10$ array of chambers, each of $300 \mu \mathrm{m}$ depth and $300 \mu \mathrm{m}$ diameter. The OSL measurements were made on a Ris $\varnothing$ TL/OSL DA-20 reader using a green $(532 \mathrm{~nm})$ laser for optical stimulation, and the ultraviolet emissions were detected by an Electron Tubes Ltd. 9235QA photomultiplier tube fitted with a $7.5 \mathrm{~mm}$ Hoya U-340 filter. Laboratory irradiations were conducted using a calibrated ${ }^{90} \mathrm{Sr} /{ }^{90} \mathrm{Y}$ beta source mounted on the reader. 
Equivalent doses $\left(\mathrm{D}_{\mathrm{e}}\right)$ were determined using a modified SAR protocol (Olley et al., 2004). A dose-response curve was constructed for each grain. OSL signals were measured for $1 \mathrm{~s}$ at $125^{\circ} \mathrm{C}$ (laser at $90 \%$ power), using a preheat of $240^{\circ} \mathrm{C}$ (held for $10 \mathrm{~s}$ ) for the 'natural' and regenerative doses, and a pre-heat of $160^{\circ} \mathrm{C}$ (held for $10 \mathrm{~s}$ ) for the test doses (5 Gy). The OSL signal was determined from the initial $0.1 \mathrm{~s}$ of data, using the final $0.2 \mathrm{~s}$ to estimate the background count rate. Each disc was exposed to infrared (IR) radiation for $40 \mathrm{~s}$ at $125^{\circ} \mathrm{C}$ prior to measurement of the OSL signal to bleach any IR-sensitive signal. Dose recovery tests were also undertaken to confirm that this treatment did not diminish the OSL signal from quartz. Grains were rejected if they did not produce a measurable OSL signal in response to the test dose, or had OSL decay curves that did not reach background after $1 \mathrm{~s}$ of laser stimulation or produced natural OSL signals that did not intercept the regenerated doseresponse curves, or had unacceptable sensitivity changes throughout the measurement cycle.

Figure 2 Map of the Cooloola dune field showing the location of the sampling sites. The soil nomenclature follows Stace et al (1958). Modified after Thompson and Moore (1984) who mapped a chronosequence showing increasing weathering, soil formation and water erosion across six geomorphically recognized soil landscapes. These landscapes were recognized from air photographs and further refined on the basis of some 150 auger holes across the dunes and the structure and floristics of the vegetation. These units are shown as DS 1 to 7(6a) in Figure $4 \mathrm{~b}$. 
Lithogenic radionuclide activity concentrations were determined using high-resolution gamma spectrometry (Murray et al., 1987). Dose rates were calculated using the conversion factors of Stokes et al., (2003) with $\beta$-attenuation factors taken from Mejdahl (1979). Cosmic dose rates were calculated from Prescott and Hutton (1994).

Burial doses were calculated using age modelling techniques of Galbraith and coworkers (Galbraith and Laslett, 1993; Galbraith et al., 1999; Roberts et al., 2000). First, the central age model was used to identify the level of over-dispersion within the single grain dose distributions. Over-dispersion is recognized as that spread in the data above that which would be expected based on just the measurement uncertainties of the individual single grain dose values. The most common cause of over-dispersion is incomplete or non-uniform bleaching, where only a (usually small) component of the grains were fully bleached by sunlight prior to burial. In these cases the 'minimum age model' isolates the lowest dose component for age estimation and the maximum age model (Olley et al., 2006) identifies highest dose component.

\section{Results}

The Cooloola samples fall into two groups and are presented in separate tables; one in which the grain population is consistent with a single equivalent dose (Table 1 and Figure 3 a and b); and the other in which a broad spread of equivalent doses is present (Table 2 and Figure 3 c and d).

Figure 3a - d: Radial plots of the data from site 17 (a) and 7a (c) [see map numbers in Tables 1 and 2]. Figure (b) and (c) shows the associated probability density functions for 


\section{the same data (solid line) shown with the samples in ranked order, the error bars are equivalent to one standard error on the mean.}

The data from site 17, sample 27, shown in Figure 3 a has an over-dispersion of 0.2. The measured $D_{e}$ (in Gy) for a grain can be read by tracing a line from the y-axis origin through the point until the line intersects the radial axis (log scale) on the right-hand side. The corresponding standard error for this estimate can be read by extending a line vertically to intersect the $\mathrm{x}$-axis. The $\mathrm{x}$-axis has two scales: one plots the relative standard error of the $\mathrm{D}_{\mathrm{e}}$ estimate (in \%) and the other ('Precision') plots the reciprocal standard error. Therefore, values with the highest precisions and the smallest relative errors plot closest to the radial axis on the right of the diagram, and the least precise estimates plot furthest to the left. Values within the light grey shaded band are within $2 \sigma$ of the dose component calculated using the Central Age Model (Galbraith and Laslett, 1993; Galbraith et al., 1999; Roberts et al., 2000) Figure $3 \mathrm{~b}$ shows a probability density function for the same data (solid line), shown with the samples in ranked order, the error bars are equivalent to one standard error on the mean. Figure $3 \mathrm{c}$ and d show similar data for sample 9, site 7a, this sample has an over-dispersion of 0.85. Values within the light grey shaded band are within $2 \sigma$ of the maximum dose component calculated using the Maximum Age Model (Olley et al., 2006) and the minimum dose component is shown between the two lines, calculated using the Minimum Age Model (Galbraith and Laslett, 1993; Galbraith et al., 1999; Roberts et al., 2000)

Table 1: Optical dates on the Cooloola dune samples, over-dispersion parameter $\left(\sigma^{\mathrm{d}}\right)$, dose rate $\left(D_{r}, G y / k a\right)$, equivalent dose $\left(D_{e}, G y\right)$ and the burial age $(k a)$. Uncertainties are equivalent to one standard error on the mean. 
Table 2: Optical dates on the Cooloola dune samples, over-dispersion parameter $\left(\sigma^{\mathrm{d}}\right)$, dose rate $\left(D_{r}, G y / k a\right)$, equivalent dose $\left(D_{e}, G y\right)$ and the burial age $(k a)$. Uncertainties are equivalent to one standard error on the mean. 
In total we believe the dunes comprise at least 10 stratigraphic units of different ages across the six geomorphic landscapes. There are possibly older, buried, units. The 10 identified are shown in a cross section in Figure 4 with the estimated ages and additional information about vegetation structure and soil profiles. The soils are more comprehensively described by Thompson (1983) and the plant communities by Walker et al., (1981) plant species are listed in Harald et al., (1987).

Figure 4: 4a shows the 10 stratigraphic units across the dunes, vegetation height and soil profiles. The youngest unit is treated as representing two events; the currently mobile dunes and the stable young dunes which may date to $0.5 \mathrm{ka}$. The 10 units identified from the dating are not readily identifiable from air photography and are not shown in Figure 2. 4b shows the Dune Sand (DS) units identified by Thompson and Moore (1984). $4 \mathrm{c}$ shows the vegetation changes across the dune field. $4 \mathrm{~d}$ shows the increasing depth of the soil horizonation across the dunefield.

\section{Discussion}

The discussion is divided into two parts; first some details about each dune system and second a discussion of how the dunes may have been formed. 


\subsection{Dune System 1}

Dune system one has two units. The first comprises mobile sand dunes. A date from the inland extremity of the Carlo Blowout (Map No.1) dates to $0.00 \pm 0.01 \mathrm{ka}$. This feature was observed as a significant feature, and sketched, in 1770 AD during Cook's passage along this coast. It is likely to be $0.4-0.5 \mathrm{ka}$ or so since initiation based on its length of travel, but this is only a rough estimate. In places, the dunes of this age have become stabilised with sparse individuals of Banksia integrifolia and in other places it is covered with establishing LowOpen Forest (nomenclature follows Walker and Hopkins 1990) of Banksia integrifolia, Banksia serrata, and Casuarina littoralis. This second unit has no soil horizonation and may date to the first phase of emplacement of this unit ( $<500$ years).

\subsection{Dune System 2}

Dune system two has one chronostratigraphic unit which dates to about 3-4 ka. A sample from location 2 at 75-85 $\mathrm{cm}$ depth gave $3.6 \pm 0.3 \mathrm{ka}$ and a sample from $80-90 \mathrm{~cm}$ gave $4.2 \pm$ $0.4 \mathrm{ka}$. It has up to $2 \mathrm{~m}$ of soil horizonation above the unaltered material and is vegetated with a mid-high Open-Forest with Banksia serrata, Casuarina torulosa, Casuarina littoralis, Eucalyptus intermedia, Eucalyptus racemosa, Lophostemon confertus, and Monotoca sp.

\subsection{Dune System 3}

Dune system three has two chronostratigraphic units, an overlying one which dates to about 6.5 ka (Map No. 4a: $6.2 \pm 0.8$ ka and Map No. 6: $6.7 \pm 0.6 \mathrm{ka}$ ) and a slightly older, underlying one which dates to about $9 \mathrm{ka}$ (Map No. 4b: $9.8 \pm 0.8 \mathrm{ka}$ and Map No.5: $8.3 \pm 0.7 \mathrm{ka}$ ). 
Soils in this landscape (unit) have developed A horizons of 80-140 cm, with pipes of bleached A horizon material extending10-15 cm into the top of the B2hir (Thompson, 1983). This unit is vegetated with a tall open- forest of Banksia serrata, Casuarina torulosa, Cinnamonum baileyanum, Eucalyptus pilularis, and Monotoca sp. and other shrubs in the lower layer.

\subsection{Dune System 4}

Dune system four samples fall into both groups (Figure 5), one in which the grain population is consistent with a single equivalent dose (Table 1; sample locations 7b, 7c, 9c, 20b) and the other in which a broad spread of equivalent doses is present (Table 2; sample locations 7a, 8 , 9a, 9b, 10,18, 20). The burial age for samples from the first group has been estimated using the central age model. Ages for the samples from locations $7 b, 7 c$, and $9 c$ are within uncertainties of one another and are consistent with a weighted mean value of $145 \pm 5 \mathrm{ka}$. The sample collected from location 20, from the sea cliff about three kilometers southeast of Rainbow Beach, gave a younger age of $118 \pm 5 \mathrm{ka}$ (this is discussed further below). For the second group of samples both the maximum and minimum ages where calculated. The maximum age model yielded ages consistent with the previous central age estimates from samples with dose distributions consistent with a single equivalent dose. This indicates that the spread in dose is observed in the second group of samples is most likely due to reworking of the dunes, such a coincidence of ages is unlikely to have arisen from other cause of dose heterogeneity. Therefore for these samples the maximum age provides the best estimate of the age of the initial emplacement of this dune system. The weighted mean age for all 
samples, calculated from the central and maximum age estimates is $146 \pm 5 \mathrm{ka}$. The ages calculated using the minimum age model, fall into two groups with weighted mean values of $68 \pm 3 \mathrm{ka}$ and $12 \pm 1 \mathrm{ka}$ respectively. These probably relate to periods of remobilization of the dunes.

The error ranges for DS4, and the underlying DS5, are greater than the time between the Last Glacial Maximum and our current interglacial. This makes it unwise to ascribe climatic processes to the transgression of the dune sands on this evidence.

Figure 5: A radial plot of the ages determined from samples collected from Dune system four. The closed circles represent ages calculated using either the maximum age model or the central age model (Table 1 and 2). They are consistent with a weighted mean of 146 \pm 5ka this probably represents the initial emplacement of this group of dunes. The triangles represent ages calculated using the minimum age model, these fall into two groups with weighted mean values of $68 \pm 3 \mathrm{ka}$ and $12 \pm 1 \mathrm{ka}$ respectively. These probably relate to periods of remobilization of the dunes.

Soil horizonation in these dunes has developed to the extent that these are properly giant podzols with A horizons up to $6.5 \mathrm{~m}$ deep and pipes of bleached $\mathrm{A}_{2}$ horizon material extending $2 \mathrm{~m}$ or more into the B horizon. This system is vegetated by an extremely tall closed forest (30-50 m tall) of Eucalyptus intermedia, Eucalyptus pilularis and Syncarpia 
glomulifera in the upper layer and Banksia integrifolia, Banksia aemula, Casuarina torulosa in the mid layer. The lower shrub layer comprises mainly Monotoca scoparia, Elaeocarpus reticulatus and Eustrephus latifolius. There is a narrow transition to simple to complex notophyll vine forests on the dune floors. These forests are 20-40 m tall and contain numerous species (Webb and Tracey, 1975). Large trees of Tristania conferta are common emergents.

\subsection{Dune System 5}

The dunes in DS 5 have lost their parabolic shape to form whale back dunes. Like dune system four, dune system five may have two chronostratigraphic units, an overlying one which dates to between $190-230 \mathrm{ka}$ and a lower, underlying one which dates to about $307 \mathrm{ka}$ (see fig. 6). A sample from map location 11 at $95-105 \mathrm{~cm}$ depth gave $228 \pm 39 \mathrm{ka}$; a sample from location 11 at $2.5-2.7 \mathrm{~m}$ gave $307 \pm 50 \mathrm{ka}$ and a sample from location 12 at $3.5-3.7 \mathrm{~m}$ gave $308 \pm 44 \mathrm{ka}$.

Figure 6: A radial plot of the ages determined from samples collected from dune system five. The closed circles represent ages calculated using either the maximum age model or the central age model (Table 1 and 2). The triangles represent ages calculated using the minimum age model 
The giant podzols that have developed on this system have A horizons which are up to $17 \mathrm{~m}$ deep with bleached $\mathrm{A}_{2}$ horizon material extending downwards into the $\mathrm{B}$ horizon for up to 5 m. This system is vegetated by a mid-high shrubby open forest of Banksia aemula, Casuarina littoralis, Eucalyptus signata and a shrubby layer mainly of Leptospermum attenuatum, and Monotoca spp.

\subsection{Dune Systems $6 a$ and $6 b$}

These dunes have lost their parabolic shape due to weathering and are either whale back dunes or low relief ridges. Both DS6 dunes Dune system 6a and 6b have dates which overlap the underlying older dates from dune system five and older dates which go back to $730 \mathrm{ka}$. This suggests that DS6 represents two units.

Dates range from $341 \pm 46 \mathrm{ka}$ from a sample from location 16 at 2.5-2.7 $\mathrm{m}$ depth; $453 \pm 81$ ka. on a sample from location 16 at 3.5-3.7 m depth; $324 \pm 41 \mathrm{ka}$ at 2.5-2.75 $\mathrm{m}$ at location 19 and $349 \pm 44 \mathrm{ka}$ on a sample from location 21 at 2.5-2.75 $\mathrm{m}$ depth.

It is vegetated by a dwarf shrubby woodland of Angophora woodsiana, Banksia aemula, Eucalyptus. intermedia, and Eucalyptus signata only 3-5m high. The dense shrubby layer consists of many shrub species including Persoonia virgata, Pimelia linifolia, Phyllota phylicoides and Leptospermum semibaccatum. The vegetation structure and species composition distinguishes it from dune system five and also the parabolic dune structure has been lost. 
DS $6 \mathrm{~b}$ occupies the western extent of the coastal dune sequence. A date of $716 \pm 92 \mathrm{ka}$ from location 15 clearly separates this site from DS6a.

This dune system is vegetated by a dwarf shrubby open woodland of Banksia aemula, Eucalyptus signata, and Eucalyptus intermedia. It has lost its dune form by either erosion or reworking and forms whaleback sandhills. The vegetation is only $3-4 \mathrm{~m}$ high and shows a morphological change to large plate-like lignotubers which are expressed by clumps of stems some 10m across (Lacey et al 1992).The deep A horizons which have formed on these systems vary in depth from 12- $22 \mathrm{~m}$ and are often saturated with water. The B horizons are typically dominated by organic material and the iron which gives the younger B horizons their reddish colour is almost completely leached out. The soils are more comprehensively described by Thompson (1983) and the vegetation by Walker et al., (1981).

\subsection{Other Samples}

Several samples dated do not fit this simple classification of the dune systems. Sample 'Mt Woolan' at location 18 at depth $2.5-2.7 \mathrm{~m}$ gave $112 \pm 17 \mathrm{ka}$, making it much younger than the other DS 4 samples. The sample was taken from the crest of an eroded high dune near Mt Woolan 2-way radio tower and Telstra repeater station about $600 \mathrm{~m}$ to the south of Lake Poona near Wide Bay at an elevation of about $230 \mathrm{~m}$. The vegetation is a eucalypt forest some $35-40 \mathrm{~m}$ tall and was mapped by Thompson as dune system four. Because the crest is so small in area Thompson was not surprised to find that the depth to Bhs was shallower than that at the Warrawonga Research site, however it was much deeper than any other Holocene dunes. The sample was taken from bright yellowish brown $\mathrm{B}_{2} \mathrm{hs}$ sand. 
Samples at location 20 were collected from the sea cliff about three kilometers southeast of Rainbow Beach. Here about $40 \mathrm{~m}$ of a giant podzol soil consistent with the morphology of dune systems four at the Warrawonga Research site was exposed by a sizeable land slip during the intense cyclones of mid 1973. The face provided access to the complete sequence of bleached $A_{2}, B 1 h s$, deep $B_{2} h s$, and $B_{3}$ hs horizons grading into thick yellow- brown dune sands (C horizon) and was used for a type site description (Thompson, 1992). The face has been considerably degraded since its exposure and only two samples were collected; sample 31 was collected from the $\mathrm{B}_{2} \mathrm{hs}$ at a depth of $6 \mathrm{~m}$ and gave an age of $118 \pm 8 \mathrm{ka}$ B.P. Sample 32 was collected from the $A_{2}$ horizon at about $2.3 \mathrm{~m}$ depth and gave an age of $163 \pm 30 \mathrm{ka}$. The apparent inversion clearly has something to do with a period of reworking. The face sampled is a single profile with no stratigraphic breaks.

An isolated patch around Mt Bilewilam, mapped as dune system five and surrounded by dune system six, gave ages confirming this mapping. Samples from location 13 at 2.7-2.9 m gave $232 \pm 35 \mathrm{ka}$, and at $3.5-3.7 \mathrm{~m}$ gave $214 \pm 22 \mathrm{ka}$.

\subsection{Summary}

The dating shows that the mapping of 6 DS units (Figure 2) does not reflect the complexity revealed by the dating. Given the difficulty of discriminating between some of the older units using air photographs, we did not attempt to map the 10 units identified.

\section{Origins of the dunes}


There are a number of hypotheses about what influences coastal dune activity (Lees, 2006; Hesp and Thom, 1990; Hesp and Walker, 2013; Hesp, 2013)

It is clear that in some places a fall in sea level exposes deposits on the shelf which are then deflated and, if the wind is onshore, transported onto the modern shoreline. Lees and Lu $(1991 ; 1992)$ argue that most of the northern Australian dune fields which have units dating to the last glacial maximum received large amounts of material in this way. They saw the existing dunes at Shelburne Bay as only a small remnant of a much larger dune field now drowned offshore on the shelf which was reworked from the palaeo-delta of the Olive River. Similar configurations can be seen at Cape Flattery with the McIvor/paleo-Endeavour River and to the south of Cape Arnhem (Lees and Lu, 1991;1992). At the latitude of Cooloola we are below the southern limit of persistent onshore winds during the LGM (Lees, 2006) and the wind regime is different.

Another model proposes that rising sea levels cause shoreface erosion and, in areas with dominant onshore winds, this destruction of foredune vegetation can allow blowouts to develop, and grow into transgressive dunes. This process was called the Cooper-Thom hypothesis by Pye (Cooper, 1958; Thom, 1978; Pye, 1984; Pye and Bowman, 1984). Young et al., (1993) argue against this latter process being the main forcing function of coastal dune transgression in eastern Australia, proposing instead that climatic changes are largely responsible. They suggest that thinning of the vegetation, increased windiness and increased storminess may all be factors. However, Thom et al., (1994) disagree with this interpretation. Larcome et al., (1995), having identified the episodic nature of sea level rise during the early Holocene in eastern Australia, point out that dune initiation could as easily be correlated with periods of transgression, regression, or stillstand. 
The most recent study by Brooke et al (2015) argue that, from their examination of Moreton Island, the onshore transport of exposed inner shelf sands was most likely to be greatest during the prolonged periods that sea level sat at intermediate levels, -20 to $-70 \mathrm{~m}$ below its present level.

This model differs substantially in emphasis from that proposed for the coastal dunes of S.E. Brazil (Mendes and Giannini, 2015) and N.E. Brazil (Tsoar et al., 2009) which tends to agree with Young et al., (1993). Tsoar et al., (2009) present a model suggesting that during the Late Pleistocene wind power determined the mobility and stability of the dunes. Sand dunes accumulated during periods of high wind power and stabilized when wind power was low. The dune stabilization process has been attributed to an increase in precipitation and decrease of wind power, both of which were correlated with the intensification of the South American Monsoon System.

Lees (1992) initially thought that climate was the main driving force for the northern Australian dunes but retracted that when a number of subsequent lake and pollen studies concluded that he was mistaken (Lees, 2006). He concluded that both sea-level change and climate were important factors. A similar model combining the sea-level change, Cooper-Thom, model and a climatic one was proposed by Porat and Botha (2008) for their study of southeast African coastal dunes. Literature for the coastal dune field evolution in south east Queensland has recently been reviewed by Miot da Silva and Shulmeister (2016). They explored the possibility of climatic or marine initiation of dune activity of these dunes. Using the limited data on dune ages then available, they felt that it was possible to identify phases of dune building associated with intermediate and high sea 
levels, but not with low, last glacial maximum (LGM), sea levels. They also felt that there was a role for tropical storms in initiating movement and that both climatic and marine effects are important controlling factors.

We will try to discuss these various hypotheses in the context of the ages presented from Cooloola.

5.1. The late Holocene ca. 300-500 years

The youngest dune system dates to between 300-500 yrs. Climatically, this was a time of considerable change. The Mediaeval Warm Period started locally at about 900 yrs before present and continued to $600 \mathrm{yrs}$ ago. At the end of this period speleothem evidence from New Zealand suggests that temperatures in this part of the world cooled rapidly to a minimum about 325 years ago (Williams et al., 2004). The estimate of the time of dune initiation sits in this cooling period of the Little Ice age. Locally, Dodson (1987) identified an increase in peat accumulation from between 200-500 years ago, consistent with a slight warming following this period. Unfortunately, the examination of possible episodic sea level change in the late Holocene carried out by Baker et al., (2001a) does not extend to the last thousand years. However, recent work by Lewis et al., (2015) on oyster deposits suggests a distinct and relatively rapid $\sim 1 \mathrm{~m}$ sea-level fall between 1200 and 800 cal. yr B.P. They were unable to determine if this was a stepped change or a smooth fall although an earlier review of the evidence by Lewis et al., (2012) felt that the evidence pointed to a stepped fall. 
This is a very widespread event. In almost every dune field examined around Australia, there is a dune transgression at about this time. From south to north, dunes of this age can be found at Kurnell (Roy and Crawford, 1981), at Newcastle Bight and Eurunderee (Thom et al., 1981a; 1981b) and on Moreton Island (Brooke et al., 2015). Lees (1995) compiled Holocene chronostratigraphic ages from coastal dunes on the Kimberley Coast (Lees et al., 1992), Cobourg Peninsula (Lees et al.,1990), Cape Arnhem (Lees et al., 1995), Groote Eylandt (Lees and Lu, 1991; 1992; Shulmeister and Lees, 1992), Shelburne Bay (Lees et al., 1990; Lees, 1992), and Cape Flattery (Pye and Switsur, 1981; Lees et al., 1990) most of which identified a unit of this age.

There is clearly a major climatic change at the time of initiation of this transgression, but the spatial distribution of activity, along the shoreline, suggests a marine trigger.

The Carlo Sandblow and the Cooloola Sandpatch are two long elongate parabolic dunes which form part of dune system one. There is an important difference between these, and the dune sands emplaced along the back of the beach during this period. The latter are a fresh accession of material to the dune field while the former, which have migrated inland from this, are disturbance events. These dunes advance and kill any vegetation they bury. As they move further forward they expose bare sand to mobilisation and, once away from the fresh transgression, this material is reworked from earlier phases of dune emplacement. They do not represent the delivery of fresh material.

\subsection{The mid-late Holocene ca. 3000-4000 ka B.P.}


The dunes which have been dated to about 3.6-4.2 ka and based on the relative dune morphology, have not travelled far, less than $0.5 \mathrm{~km}$, and so these ages are probably well within 100-200 years of the initiation event. Again, these are elongate parabolic dunes and the dates represent a reworking event. There may have been some delivery of fresh material, but any evidence of this has either been reworked by the younger transgression, or is buried beneath it.

There is again a fairly widespread global climate shift at this time. Locally, Dodson noted a change from clay to peat deposition in mires at Barrington Tops (Dodson, 1987), suggesting the development of cooler and possibly drier environments. Conversely, at Hidden Lake on Fraser Island Longmore (1998) sees this period as the end of her mid- Holocene dry phase. The Hidden Lake record could indicate a cooler phase, with less evaporation, making sense of the record from both sites.

Baker et al., (2001a) fitted a number of curves to existing data for sea level during the Holocene to examine which might give the best fit. In Baker et al., (2001a) paper their sea level curve suggests that this time is the start of a stillstand in the seventh order polynomial, and a slight sea level rise in the eighth order polynomial. Shepherd and Elliot (1995) identified two major episodes of marine erosion on the Western Australian coastline during the Holocene. At four locations they identified an episode between 2-3 ka, and at two locations an episode between 6.7-6 ka. They suggest that the younger event was associated with either increased storminess or a minor marine transgression. There was no evidence for major episodes of marine erosion at other times during the Holocene. The former event was associated with the initiation of transgressive dunes, the classic Cooper-Thom model. 
In most of the coastal dune fields to the south, and to the north, of Cooloola a similar transgressive episode has been identified. To the south, this transgression appears to match the time of emplacement of a transgressive dune episode at Kurnell and the second phase of dune development at Eurunderee (Roy and Crawford,1981; Thom et al., 1981).

\subsection{The early Holocene}

The oldest Holocene system, DS3, appears to be a single discrete, geobotanical unit but is made up of two chronostratigraphic units. Allowing some 600 years for the dunes to migrate to the dating location, we are looking at initiation at about 6 kaand $8-9 \mathrm{ka}$ ago. Once again, these are elongate parabolic dunes and represent a period of reworking following initiation at the coast.

Looking at Queensland data, Larcome et al., (1995) have produced good evidence for episodic sea level rise in the early Holocene. Their data shows that the rising sea level was interrupted by stillstands and minor regressions. Within the range of their data, they show a stillstand or minor fall at about $10.5 \mathrm{ka}$, a significant fall between 8.5 and $8.2 \mathrm{ka}$, and stillstands or minor falls at about $7.8 \mathrm{ka}, 6.0 \mathrm{ka}$ and $5.5 \mathrm{ka}$. Looking at NSW data, Sloss et al., (2007) found a similar, oscillating model with possible oscillations of up to a maximum of $1.7 \mathrm{~m}$ above PMSL between 4 and $3.2 \mathrm{ka}$ but were unable to quantify the range owing to uncertainties about changes in tidal range, wave climate and the configuration of the nearshore zone. 
The error ranges make it impossible to tie dune transgression into a stillstand or fall in sea level, and possible climate reversal, or to periods of fairly rapid sea level rise. As Larcome et al., (1995) point out, the apparently widespread emplacement of coastal dunes at 8.58.2 ka could reasonably be attributed to either. Given the fluctuation in sea level which apparently took place at that time, the event could represent the deflation of a recently emplaced shoreline which, having no profile development to bind it, was particularly susceptible to mobilisation. As more, and better, information about sea level change and the times of dune emplacement become available, the picture is becoming harder to interpret. The confidence of Pye and Bowman (1984) and Lees et al., (1995) in the Cooper-Thom model is now hard to justify.

Looking at climatic drivers, locally, Longmore (1998) identified a mid-Holocene dry period in her investigation of perched lake sediments in Fraser Island. Her most detailed investigation was of Hidden Lake. She found that independent sedimentological, palynological and palaeolimnological evidence all combined to indicate persistently shallower lake conditions between 8.5 and $2.5 \mathrm{ka}$ ago, with a minimum depth occurring at 5.5 ka. Lake levels remained low until $4.5 \mathrm{ka}$, following which it rose to $2.5 \mathrm{ka}$. Support for this was found at the ephemeral Old Lake Coomboo Depression (Longmore, 1998). Similar findings by Donders et al., (2006) were based on palynological examination of a well dated core from Lake Allen, Fraser Island. They found an early Holocene dry phase with conditions changing after $5.5 \mathrm{ka}$ with higher lake levels until $3 \mathrm{ka}$ after which there were more variable and drier conditions. Brooke et al., (2015) identified a dune sand unit dating to $5.75 \pm 0.53 \mathrm{ka}$. on nearby Moreton Island possibly associated with this drying out. 
Evidence of a drying out locally between $8.5 \mathrm{ka}$ and $5.5 \mathrm{ka}$, implies that any dune transgression which was initiated during this period could progress for an extended period before stabilisation took place. But the dune transgression at Cooloola at the start of the Holocene preceded this climatic change. There is no dune activity at Cooloola which corresponds to the apparently more favourable (for dune transgression) climate.

The best explanation for this transgression is that the highly variable climate identified by Nott et al, (1999), linked with the sea level fluctuations identified by Larcome et al., (1995), produced conditions where the initiation of a transgression and its continued movement were possible.

\subsection{The Pleistocene at Cooloola}

The older chronostratigraphic units, covering DS4 to DS6, have error ranges which are too broad for any sensible discussion about what might have initiated them. It is likely that they are composite units. Dune system four dates to between $130-150 \mathrm{ka}$. with eight dates which overlap at one standard deviation. They place the unit as having formed at about the time of the last interglacial high sea level.

These ages are similar to the ${ }^{230} \mathrm{Th} /{ }^{234} \mathrm{U}$ isotopes ages of $120-135$ ka reported by Pickett et al., $(1985 ; 1989)$ on coral buried by a prograding shoreline and parabolic dune as North Stradbroke Island formed. The overlying dune system was dated using TL by Tejan-Kella et al., (1990) to $120 \pm 11 \mathrm{ka}$. 
Esat et al., (1999) have identified rapid fluctuations in sea level at Huon Peninsula during the 116-136 ka period with rises and falls of up to $90 \mathrm{~m}$. Their record for this period shows a brief period of lower than present high sea level at about $136 \mathrm{ka}$, followed by a dramatic fall of about $80 \mathrm{~m}$ then a rapid rise to a few meters above present sea level at about $128 \mathrm{ka}$, stability until about $118 \mathrm{ka}$, followed by a drop of about $50 \mathrm{~m}$, and another rise to about $-10 \mathrm{~m}$ at about $100 \mathrm{ka}$. Sea level then fell. Prior to this, sea level seems to have been lower, but within $50 \mathrm{~m}$ of present sea level, for short periods at about 200 and $170 \mathrm{ka}$. The period 170-145 ka. was a period of lowering sea level, with a number of fluctuations, and the period 145-136 ka. was apparently a period of rapid rise from about-140 m depth. These changes appear to be so rapid that, even though most of the dates for dune system four overlap at a standard deviation, the dating uncertainty makes it impossible to suggest much more than a trigger event around $130-145 \mathrm{ka}$. DS 4 is a very large dune and could have taken a long time to stabilize and been subject to several events.

This is a similar pattern to that found in the Cape York dune fields (Lees et al., 1990; 1995; Lees and Lu, 1992) where some transgressions represent the delivery of significant amounts of material to the dune field, and others represent periods of reworking. In these dune fields to the north, the delivery of significant amounts of material to the dune field took place during the last glacial when the deltas of local rivers were extensively reworked, remobilised and transported onshore. Here it is not clear which of these episodes, if any, represents accession of material to the dune field.

Some quite extreme sea level and climatic changes have not left evidence of dune transgression at Cooloola. Rapid climate and sea level changes identified in ice cores and on Huon Peninsula between 65-30 ka (Chappell, 2002), for instance, have no equivalent dune 
sand unit that has been identified. Here, where the dune chronosequence is a long one, it is possible to make some inferences on the basis of the absence of features. There seem to be some straightforward limiting factors to dune transgression at Cooloola. The sediment source offshore consists of quartz sands out to the mid-shelf, beyond which are mixed carbonatequartz sands (32-40 m depth) and carbonate sands 36-90 m depth). Both of these are likely to become cemented early in their subaerial exposure and not feed into extensive dune transgressions. It would seem probable that dune transgression into this dune field only occurs during periods when the inner and middle shelf sands are devegetated or disturbed to some extent when sea level rises to above $-36 \mathrm{~m}$. Most of the climatic changes alone have not been sufficient to mobilise the sand body.

\subsection{Last glacial maximum}

Unlike major dune fields to the north and south, the Cooloola-Fraser Island area does not seem to have any unit on land corresponding to the last glacial maximum around 18ka before present. This may be because the source of the sediments is an alongshore transport system which lies to the east, and during the last glacial maximum the dominant winds here were offshore (Thiede, 1979; Wasson, 1987). Any deflation of sediments exposed on the shelf would have built dunes to the east, which would now be underwater. Evidence of such features has been identified in work by Stephens (1982) and Kudrass (1982). Cores in 20-30 $\mathrm{m}$ water depth frequently turn up humate cement indicating reworked Pleistocene dune soils. 


\subsection{Older Units}

The error ranges of units older than the Last Glacial Maximum are such that they could span major events including both low sea level and high sea levels and mean that ascribing specific processes to them is still impossible.

\section{Conclusion}

Cooloola is one of the most chronostratigraphically consistent coastal dune sequences in Australia. Close by we have good sites for climatic reconstruction at Barrington Tops and the Fraser Island lakes. Larcome et al., (1995) and Baker et al., (2001a) have produced high resolution models for local sea level and Esat et al., (1999) and Yokoyama and Esat (2011) provide a great deal of insight into the fluctuating nature of sea level during the last interglacial. As Yokoyama and Esat (2011) point out, climate change and sea level change are often linked inextricably making the driving process for dune building harder than ever to explain. What does seem clear is that most of the dune transgressions identified at Cooloola were initiated along the coastline. This implies a climate which limits the ability of vegetation to colonise and stabilise moving sand, but not extreme enough to provide the initial trigger, nor adverse enough to allow small blowouts to grow. This process is also limited to times when sea level is within 36-40 m below the present level.

Some events, such as the 4-500 year transgression and the 3-4,000 year transgression, do seem to correspond to similar units at other locations. However, there are far fewer Holocene units here than in many other coastal dune fields on this east coast and those 
that are present do seem to indicate regional events. It is dangerous to assert this with any confidence as most of the coastal dune fields to the south have ages inferred from ${ }^{14} \mathrm{C}$ dates on other material, and those to the north have only been minimally sampled. Given the error ranges around the Pleistocene dates, and the evidence for rapid short term fluctuation in sea level and, presumably, climate, described by Yokoyama and Esat (2011) very little can be said about them.

These dates finally tie the discussion of soil formation on these deeply drained coastal sands to what we believe is a reliable age scale. Previous discussion of the soils (Thomson, 1981; 1983; 1992) and soil-vegetation interactions (Walker et al., 1981; 1983; 1987; 1989; Thomson and Walker, 1987; Wardle et al, 2004; Chen et al., 2015) relied either on inferred ages, or preliminary results.

The giant Humus Podzols of DS6, with A horizons of more than $25 \mathrm{~m}$ in places (Thompson and Moore, 1984), are now clearly between $350 \mathrm{ka}$ and $730 \mathrm{ka}$ in age. The giant Podzols of DS5, with A horizons of more than $18 \mathrm{~m}$ in places, are 200-300 ka in age. The giant Podzols of DS4, with A horizons of between 8 and $12 \mathrm{~m}$, are between 130-150 ka. The dune Podzols of DS3, with A horizons of 2-6 $\mathrm{m}$ in freely drained locations, are 6-9 ka. The young Podzols of DS2, with $2 \mathrm{~m}$ of soil horizonation, are 3-4 ka and DS1, the most modern unit, has no soil horizonation.

Importantly, the results show that ecosystem succession and decline observed in many dune ecosystems is directly related to the age of the soil with maximum biomass occurring on dunes which date to the last interglacial, 130-150 ka, and ecosystem decline on dunes older than that. This phenomenon may only be observable in landscapes that escaped 
glaciation during the late Pleistocene. The coastal dunes of northern and eastern Australia have fragments of this picture but the Cooloola dune field has the best example found to date.

\section{Acknowledgements}

Blank for reviewing

\section{References}

Aitkin, M. J., 1998. An introduction to optical dating: the dating of Quaternary sediments by the use of photon-stimulated luminescence. Oxford; New York, Oxford University Press.

Baker, R. G. V., Haworth, R. J. Flood, P. G., 2001a. Intertidal fixed indicators of former Holocene sea levels in Australia: a summary of sites and methods. Quaternary International, $83-85,257-273$.

Baker, R. G. V., Haworth, R. J., Flood, P. G., 2001b. Warmer or cooler late Holocene marine palaeoenvironments?: interpreting southeast Australia and Brazilian sea level changes using fixed biological indicators and their ${ }^{18} \mathrm{O}$ composition. Palaeogeography, Palaeoclimatology, Palaeoecology, 168, 249-272.

Boyd, R., Goodwin, I., Ruming, K. Davies, S., 2004a. River of Sand; a geological perspective on the evolution of Fraser Island and surrounding seabed. Abstracts of Fraser Island Defenders Organisation, A 2020 vision for Fraser Island: A new focus for the Great Sandy World Heritage Area Conference, Noosa, August 2004.

Boyd, R., Ruming, K., Davies, S., Payenberg, T., Lang, S., $2004 b$.

Fraser Island and Hervey Bay - A Classic Modern Sedimentary Environment Proc., PESA Eastern Australian Basins Symposium II, Adelaide, South Australia, Septemper 2004. http://www.newcastle.edu.au/discipline/geology/research/EOS/Fraser/EOSfraser.htm 
Bridge, B.J., Ross, P.J., Thompson, C.H., 1985. Studies in landscape dynamics in the Cooloola-Noosa River area, Queensland. 3. Sand movement on vegetated dunes. 41p. CSIRO Aust. Div. Soils Divisional Report No. 73

Brooke, B. P., Pietsch, T.J., Olley, J.O., Sloss, C.R., Cox, M.E., 2015. A preliminary OSL chronology for coastal dunes on Moreton Island, Queensland, Australia -Marginal deposits of a large-scale Quaternary shelf sediment system. Continental Shelf Research, 105, 79-94.

Chappell, J., 2002. Sea level changes forced ice breakouts in the Last Glacial cycle: new results from coral terraces. Quaternary Science Reviews, 21(10) 1229-1240.

Chen, C.R., Hou, E.Q., Condron, L.M., Bacon, G., Esfandbod, M., Olley, J., Turner, B.L., 2015. Soil phosphorous fractionation and nutrient dynamics along the Cooloola coastal dune chronosequence, southern Queensland, Australia. Geoderma, 257, 4-13.

Coaldrake, J.E., 1962. The coastal sand dunes of southern Queensland. Proc. R.Soc.Qld. 72, 101-116.

Cooper, W.S., 1958. Coastal sand dunes of Oregon and Washington. Mem. Geol. Soc. Am. No. 72.

Dodson, J.R., 1987. Mire development and environmental change, Barrington Tops, NSW. Australia. Quaternary Research, 27, 73-81.

Donders, T.H., Wagner, F., Visscher, H., 2006. Late Pleistocene and Holocene subtropical vegetation dynamics recorded in perched lake deposits on Fraser Island, Queensland, Australia. Palaeogeography, Palaeoclimatology, Palaeoecology 241. 417-439.

Esat, T.M., Mcculloch, M.T., Chappell, J., Pillans, B., Omura, A., 1999. Rapid fluctuations in sea level recorded at Huon Peninsula during the penultimate deglaciation. Science, 283(5399), 197-201. 
Galbraith. R. F., Laslett, G. M., 1993, Statistical models for mixed fission track ages. Radiation Measurements 21, 459-470.

Galbraith, R.F., Roberts, R.G., Laslett, G.M., Yoshida, H., Olley, J.M., 1999. Optical dating of single and multiple grains of quartz from Jinmium rock shelter, northern Australia, part 1, Experimental design and statistical models. Archaeometry 41, 339-364.

Gontz, A.M., Moss, P.T., Wagenknecht, E.K., 2014. Stratigraphic Architecture of a Regressive Strand Plain, Flinders Beach, North Stradbroke Island, Queensland, Australia. Journal of Coastal Research 30(3), 575-585.

Gontz, A.M., McCallum, A.B., Moss, P.T., Shulmeister, J., 2016. Ground Penetrating Radar Observations of Present and Former Coastal Environments, Great Sandy National Park, Queensland, Australia - Focus on Moon Point, Fraser Island. Journal of Coastal Research, Special Issue: 75(2), 730-734.

Harrold, A.G., Mcdonald, W.J.F., Hopkins, M.S., Walker, J., Sandercoe, C.S., Thompson, C.H., 1987. Studies in landscape dynamics in the Cooloola-Noosa area, Queensland. 5. Vascular plants. Divisional Report. Division of Soils. CSIRO Australia. (89): 54p. 39 refs.

Hesp, P.A., 2013. Conceptual models of the evolution of transgressive dunefield systems. Geomorphology 199: 138-149.

Hesp, P.A., Thom, B.G. 1990. Geomorphology and evolution of active transgressive dunefields. In K.F. Nordstrom, N.P. Psuty, R.W.G. Carter (Eds.), Coastal Dunes: Form and Process, John Wiley and Sons, Chichester (1990), pp. 253-288

Hesp, P.A.,Walker, I.J., 2013. Aeolian environments: coastal dunes. In: Shroder, J. (Editor in Chief), Lancaster, N., Sherman, D.J., Baas, A.C.W. (Eds.), Treatise on Geomorphology, vol. 11, Aeolian Geomorphology. Academic Press, San Diego, CA, pp. 109-133. 
Kudrass, H.R., 1982. Cores of Holocene and Pleistocene sediments for the East Australian continental shelf (SO-15 cruise 1980). Geologisches Jahrbuch, Reihe D, Mineralogie, Petrologie, Geochemie, Lagerstattenkunde, 56, 137-163.

Larcombe, P., Carter, R.M., Dye, J., Gagan, M.K., Johnson, D.P., 1995. New evidence for postglacial sea level rise, central Great Barrier Reef, Australia. Marine Geology, 127, 1-44.

Lees, B.G., Head, J., Lu, Y.C., 1990. Reconnaissance Thermoluminescence dating of northern Australian coastal dune systems. Quaternary Research, 34, 169-185.

Lees, B.G., Lu, Y.C., 1991. Quaternary aeolian deposits in the Gulf of Carpentaria region, northern Australia. Kexue Tongbao, 36, 1484-1486.

Lees, B.G., 1992. Geomorphological evidence for late Holocene climate change in northern Australia. Australian Geographer, 23; 1-11.

Lees, B.G., Lu, Y.C., 1992. A preliminary study on formation of the sand dune systems in the northern Australian coastal zone. Chinese Science Bulletin, 37,587-592.

Lees, B.G., Price, D., Lu, Y.C., 1992. Thermoluminescence dating of dunes at Cape St. Lambert, East Kimberleys, northwestern Australia. Marine Geology, 106,131-139.

Lees, B.G., Hayne, M., D. Price., 1993. Marine transgression and dune initiation on western Cape York, northern Australia. Marine Geology, 114, 81-89.

Lees, B.G., Stanner, J., Price, D., Lu, Y.C., 1995. Thermoluminescence dating of dune podzols at Cape Arnhem, northern Australia. Marine Geology, 129, 63-75.

Lewis, S.E., Sloss, C.R., Murray-Wallace, C., Woodroffe, C.D., Smithers, S.G., 2012. Postglacial sea-level changes around the Australian margin: A review. Quaternary Science Reviews, 74, 115-138. 
Lewis, S.E, Wust, R.A.J., Webster, J.M., Collins, J., Wright, S.A., Jacobsen, G., 2015. Rapid relative sea-level fall along north-eastern Australia between 1200 and 800 cal.yr B.P.: An appraisal of the oyster evidence. Marine Geology,, 370, 20-30.

Levin, N., Neil, D., Syktus, J., 2014. Spatial variability of dune form on Moreton Island, Australia, and its correspondence with wind regime derived from observing stations and reanalyses Aeolian Research 15, 289-300.

Linsley, B. K., Wellington, G. M., Shrag, D. P., 2000. Decadal sea surface temperature variability in the subtropical South Pacific from 1726 to 1997 A. D. Science, 290, 1145 1148

Longmore, M.E., 1998. The mid Holocene dry anomaly on the mid eastern coast of Australia: calibration of palaeowater depth as a surrogate for effective precipitation using sedimentary loss on ignition in the perched lake sediments of Fraser Island, Queensland. Palaeoclimates, 3, 135-160.

Marshall, J.F., 1977. Marine geology of the Capricorn Channel area. Bull. Bur. Miner. Resour. Geol. Geophys. Aust., 163.

Mejdahl, V., (1979). "Thermoluminescence dating; beta-dose attenuation in quartz grains." PACT 3(2): 457.

Mendes, V.R., Giannini, P.C.F. 2015. Coastal dunefields of south Brazil as a record of climatic changes in the South American Monsoon System. Geomorphology, 246, 22-34.

Miot da Silva, G., Shulmeister, J., 2016. A review of coastal dunefield evolution in Southeastern Queensland. In:Vila-Concejo, A.; Bruce, E.; Kennedy, D.M., and McCarroll, R.J. (eds.), Proceedings of the 14th InternationalCoastal Symposium (Sydney, Australia). Journal of Coastal Research, Special Issue, No. 75, pp. 308-312. CoconutCreek (Florida),

Muckersie, C., Shepherd, M. J. 1995. Dune phases as time-transgressive phenomena, Manawatu, New Zealand. Quaternary International, 26, 61-67. 
Murray, A.S., Marten, R., Johnston, A., Martin, P., 1987. Analysis for naturally occurring radionuclides at environmental concentrations by gamma spectrometry. Journal of Radioanalytical and Nuclear Chemistry, Articles 115, 263-288.

Nott, J., Bryant, E. A., Price, D. M., 1999. Early-Holocene aridity in tropical northern Australia. The Holocene, 9, 231-236.

Olley, J.M., Pietsch, T., Roberts, R.G., 2004. Optical dating of Holocene sediments from a variety of geomorphic settings using single grains of quartz. Geomorphology, 60, 337-358

Olley, J., Roberts, R., Yoshida, H., Bowler, J., 2006. Single-grain optical dating of graveinfill associated with human burials at Lake Mungo, Australia. Quaternary Science Reviews, 25 (no. 19-20): 2469-2474.

Peltzer, D. A., Wardle, D. A., Allison, V. J., Baisden, W. T., Bardgett, R. D., Chadwick, O.A., Condron, L.M., Parfitt, R.L., Porder, S., Richardson, S.J., Turner, B.L., Vitousek, P.M. Walker, J., Walker, L.R., 2010. Understanding ecosystem retrogression. Ecological Monographs 80 (4) 509-529

Petherick, L., Bostock, H., Cohen, T.J.,Fitzsimmons, K., Tibby, J., Fletcher, M.S., Moss, P., Reeves, J., Mooney, S., Barrows, T., Kemp, J., Jansen, J., Nanson, G., Dosseto, A., 2013. Climatic records over the past $30 \mathrm{ka}$ from temperate Australia - a synthesis from the OzINTIMATE workgroup. Quaternary Science Reviews 74, 58-77.

Pickett, J.W., Thompson, C. H., Kelley, R.A., Romans, D., 1985. Evidence of high sea-level during isotope stage-5c in Queensland, Australia. Quaternary Research. 31. 392-395.

Pickett, J.W., Ku, T.L., Thompson, C. H., Kelley, R.A., Romans, D., Kelley, R.A., Huang, Y.P., 1989. A Review of Age Determinations on Pleistocene Corals in Eastern Australia. Quaternary Research, 24(1) 103-114.

Porat, N., Botha, G. 2008. The luminescence chronology of dune development on the Maputaland coastal plain, southeast Africa. Quaternary Science Reviews, 27, 1024-1046. 
Prescott, J. R., Hutton, J. T., 1994. "Cosmic-Ray Contributions to Dose-Rates for Luminescence and ESR Dating - Large Depths and Long-Term Time Variations." Radiation Measurements 23(2-3): 497-500.

Pye, K., 1982. Morphological development of coastal dunes in a humid tropical environments, Cape Bedford and Cape Flattery, North Queensland. Geogr. Ann., A64, 213227.

Pye, K., 1983. Formation and history of Queensland coastal dunes Zeits. Geomorph. Suppl. Bodenkd, 45, 175-204.

Pye, K., 1984. Models of transgressive coastal dune building episodes and their relationship to Quaternary sea level changes: a discussion with reference to evidence from eastern Australia. In M. Clark (ed), Coastal Research: UK perspectives, Geo Books, Norwich, 81104.

Pye, K., Bowman, G. M., 1984. The Holocene marine transgression as a forcing function in episodic dune activity on the eastern Australian coast. In: B.G. Thom (ed) Coastal Geomorphology in Australia. Academic Press, Sydney, pp. 179-192.

Pye, K., Switsur, V.R., 1981. Radio-carbon dates from the Cape Bedford-Cape Flattery dunefield, North Queensland. Search, 12, 225-226.

Reeve, R., Fergus, I.F., Thompson, C.H., 1985 Studies in landscape dynamics in the Cooloola-Noosa River area, Queensland. 4. Hydrology and water chemistry. CSIRO Aust. Div. Soils Divisional Report No. 73 42p.

Roberts, R.G., Galbraith, R.F., Yoshida, H., Laslett, G.M., Olley, J.M., 2000. Distinguishing dose populations in sediment mixtures: a test of single-grain optical dating procedures using mixtures of laboratory-dosed quartz. Radiation Measurements 32, 459-465. 
Ross, D.J., Bridge, B.J., Fergus, I.F. Forth, J.R., Prebble, R.E., Reeve, R., 1984. Studies in landscape dynamics in the Cooloola-Noosa River area, Queensland. 2.Field measurement techniques. CSIRO Aust. Div. Soils Divisional Report No. 73. 46p.

Roy, P. S., Crawford, E. A., 1981. Holocene the geological evolution of the southern Botany Bay-Kurnell region, central New South Wales coast. Records of the Geological Survey of New South Wales, 20(2), 159-250.

Roy, P. S., Thom, B. G., 1981. Late Quaternary marine deposition in NSW and southern Queensland - an evolutionary model. J. Geol. Soc. Aust. 28, 471-489.

Shepherd, M. J., Eliot, I. G., 1995. Major phases of coastal erosion ca. 6700-6000 and ca. 3000-2000 B. P., between Cervantes and Dongara, Western Australia. Quaternary International, 26, 125-130.

Shulmeister, J., Lees, B.G., 1992. Morphology and chronostratigraphy of a coastal dunefield, Groote Eylandt, northern Australia. Geomorphology, 5, 521-534.

Sircombe, K.N., 1999. Tracing provenance through the isotope ages of littoral and sedimentary detrital zircon, in Eastern Australia. Sedimentary Geology 124, 47-67.

Sloss,C.R., Murray-Wallace, C.V., Jones, B.G., 2007. Holocene sea-level change on the southeast coast of Australia: a review. The Holocene 17(7). 999-1014

Stace, H.C.T., Hubble, G.D., Brewer, R., Northcote, K.H., Sleeman, J.R., Mulcahy, M.J., Hallsworth, E.G., 1968. A Handbook of Australian Soils. Rellim. Tech. Publs,: Adelaide.

Stephens, A. W., 1982. Surficial sediments of the southern Queensland shelf: SouthportPoint Lookout and Fraser Island areas. Geologisches Jahrbuch, Reihe D, Mineralogie, Petrologie, Geochemie, Lagerstattenkunde, 56, 125-135.

Stokes, S., Ingram, S., Aitken, M.J., Sirocko, F., Anderson, R., Leuschner, D., 2003. Alternative chronologies for Late Quaternary (Last Interglacial-Holocene) deep sea sediment via optical dating of silt-sized quartz. Quaternary Science Reviews 22, 925-941. 
Tejan-Kella, M.S., Chittleborough, D.J., Fitzpatrick, R.W., Thompson, C.H., Prescott, J.R., Hutton, J.T., 1990. Thermoluminescence dating of coastal sand dunes at Cooloola and North Stradbrooke Island, Australia. Aust.J.Soil Res., 28, 465-481.

Thiede, J., 1979. Wind regimes over the late Quaternary southwest Pacific Ocean. Geology, 7, 259-262.

Thom, B.G., 1965. Late Quaternary coastal morphology of the Port Stephens-Myall Lakes area, NSW. J.Roy.Soc. NSW., 98: 23-26.

Thom, B.G., 1978. Coastal sand deposition in southeast Australia during the Holocene. In: J. L. Davies and M. A. J. Williams (eds), Landform evolution in Australasia, ANU Press, Canberra, 197-214.

Thom, B.G., Bowman, G.M., Roy, P.S., 1981a. Late Quaternary evolution of coastal sand barriers, Port Stephens-Myall Lakes area, central New South Wales, Australia. Quaternary Research, 15, 345-364.

Thom, B.G., Bowman, G.M., Gillieson, R., Polach, H.A., Barbetti, M., 1981b. Radiocarbon dating of Holocene beach-ridge sequences in South East Australia. .Geogr. Dept. Univ. NSW., Duntroon, Monograph 11.

Thom, B.G., Hesp, P.A., and Bryant, E. 1994. Last Glacial coastal dunes in Eastern Australia and implications for landscape stability during the Last Glacial Maximum. Palaeo 3 v.111: 229-248.

Thompson, C. H., 1981. Podzol chronosequences on coastal dunes in eastern Australia. Nature, 291, 59-61.

Thompson, C. H., 1983. Development and weathering of large parabolic dune systems along the sub-tropical coast of eastern Australia. Geomorphology, Suppl. 45, 205-225 
Thompson, C. H., 1992. Genesis of podzols on coastal dunes in southern Queensland. I. Field relationships and profile morphology. Aust. J. Soil Res., 30, 593-613.

Thompson, C. H., Moore, A. W., 1984. Studies in landscape dynamics in the CooloolaNoosa River area, Queensland. 1. Introduction, general description and research approaches. 93p. CSIRO Aust. Div. Soils Divisional Report No. 73.

Thompson, C. H., Walker, J., 1987. Temporal changes in soils and vegetation on subtropical coastal dunes, Cooloola, Queensland, Australia-a synthesis. Proc. Welsh Soils Discussion Group Meeting "Soils and the time factor", Aberystwyth, May 1983, RHIF ADRODDIAD Rep. No. 24. pp. 113-133.

Tsoar, H., Levin, N., Porat, N., Maia, L.P., Herrmann, H., Tatumi, S.H., Claudino-Sales, V. 2009. The effect of climate change on the mobility and stability of coastal sand dunes in Ceara State (NE Brazil). Quaternary Research, 71(2), 217-226.

Walker, J., Hopkins, M.S., 1990. Vegetation. In: Australian Soil and Land Survey Handbook ed. McDonald, R.C., Isbell, R.F., Speight, J.G., Walker, J., and Hopkins M.S. Inkata Press, Melbourne and Sydney.

Walker, J., Thompson, C. H ., Fergus, I. F., Tunstall, B. R., 1981. Plant succession and soil development in coastal dunes of eastern Australia. In: D. C. West, H. H. Shugart and D. B. Botkin (eds) Forest Succession: Concepts and Application. p. 107-131. Springer-Verlag, New York.

Walker, J., Thompson, C. H., Jehne, W., 1983. Soil weathering stage, vegetation succession, and canopy dieback. Pacific Science, 37(4), 471-481.

Walker, J., Thompson, C. H., Lacey, C. J., 1987. Morphological difference in lignotubers of Eucalyptus intermedia and E. signata associated with different stages of podzol development on coastal dunes, Cooloola, Queensland. Aust. J. Bot., 35, 301-311.

Ward, W.T., 1977. Sand movement on Fraser Island: A response to changing climates. Univ. Qld. Dept. Anthrop. Papers, 8, 113-126. 
Ward, W.T., 2006. Coastal dunes and strandplains in southeast Queensland: sequence and chronology. Australian Journal of Earth Sciences 53(2), 363-373.

Wardle, D.A., Walker, L.R, Bardget, R.D., 2004. Ecosystem properties and forest decline in contrasting long-term chronosequences. Science 305(5683), 509-513.

Wasson, R.J., 1987. The Australian continental dune field and past atmospheric circulation. in: T.H. Donnelly and R. J. Wasson (eds), Extended Abstracts, CLIMANZ 3 Symp. CSIRO Div. Water Resour., Canberra. p.83-87.

Webb, L.J., Tracey, J.G. 1975. The Cooloola rainforests. Proc.Ecol.Soc.Aust. 9, 317-321.

Williams, P. W., King, D. N. T., Zhao, J. X. Collerson, K. D., 2004. Speleothem master chronologies: combined Holocene ${ }^{18} \mathrm{O}$ and ${ }^{13} \mathrm{C}$ records from the North Island of New Zealand and there Palaeo Environmental interpretation. The Holocene, 14, 194-208.

Yan, N., Baas, A. C. 2015. Parabolic dunes and their transformations under environmental and climatic changes: towards a conceptual framework for understanding and prediction. Global and Planetary Change, 124, 123-148.

Young, R. W., Bryant, E.A, Price, D. M., Pease, M., 1993. Theoretical constraints and chronological evidence of Holocene coastal development in central and southern New South Wales, Australia. Geomorphology, 7, 317-32. 
Table 1

\begin{tabular}{|ccccccccccc|}
\hline $\begin{array}{c}\text { Sample } \\
\text { number }\end{array}$ & Map no & $\begin{array}{c}\text { Depth } \\
\mathrm{cm}\end{array}$ & \multicolumn{1}{c}{$\sigma_{\mathrm{d}}$} & \multicolumn{2}{c}{$\mathrm{Dr}$} & \multicolumn{2}{c|}{ De } & \multicolumn{2}{c|}{ Burial age } \\
\hline 1 & 1 & $25-35$ & 0.00 & 0.64 & 0.04 & 0.02 & 0.01 & 0.0 & 0.0 \\
2 & 2 & $75-85$ & 0.16 & 0.87 & 0.07 & 3.15 & 0.14 & 3.6 & 0.3 \\
3 & 3 & $80-90$ & 0.00 & 0.45 & 0.03 & 1.89 & 0.10 & 4.2 & 0.4 \\
4 & $4 \mathrm{a}$ & $75-85$ & 0.39 & 0.75 & 0.06 & 4.62 & 0.47 & 6.2 & 0.8 \\
5 & $4 \mathrm{~b}$ & $90-120$ & 0.00 & 0.56 & 0.04 & 5.49 & 0.25 & 9.8 & 0.8 \\
6 & 5 & $75-85$ & 0.11 & 0.73 & 0.05 & 6.09 & 0.21 & 8.3 & 0.7 \\
7 & 6 & $70-80$ & 0.00 & 0.85 & 0.07 & 5.65 & 0.20 & 6.7 & 0.6 \\
13 & $9 \mathrm{c}$ & $350-370$ & 0.25 & 0.24 & 0.01 & 34.9 & 1.4 & 146 & 11 \\
15 & $7 \mathrm{~b}$ & $250-270$ & 0.21 & 0.36 & 0.02 & 50.0 & 1.9 & 140 & 11 \\
16 & $7 \mathrm{c}$ & $350-370$ & 0.18 & 0.30 & 0.02 & 43.9 & 1.4 & 147 & 11 \\
27 & 17 & $250-270$ & 0.20 & 0.34 & 0.02 & 121.7 & 6.5 & 362 & 30 \\
31 & $20 \mathrm{~b}$ & 600 & 0.26 & 0.47 & 0.02 & 55.6 & 2.9 & 118 & 8 \\
\hline
\end{tabular}


Table 2

\begin{tabular}{|c|c|c|c|c|c|c|c|c|c|c|c|c|c|}
\hline $\begin{array}{l}\text { Sample } \\
\text { number }\end{array}$ & $\begin{array}{c}\text { Map } \\
\text { no }\end{array}$ & $\begin{array}{c}\text { Depth } \\
\mathrm{cm}\end{array}$ & $\sigma_{d}$ & \multicolumn{2}{|c|}{$\mathrm{Dr}$} & \multicolumn{2}{|c|}{ Minimum De } & \multicolumn{2}{|c|}{ Min age } & \multicolumn{2}{|c|}{ Maximum De } & \multicolumn{2}{|c|}{ Max Age } \\
\hline 9 & $7 a$ & $125-135$ & 0.80 & 0.40 & 0.03 & 5.13 & 0.88 & 13 & 2 & 50.6 & 5.8 & 126 & 17 \\
\hline 11 & 8 & $115-125$ & 0.85 & 0.20 & 0.01 & 3.13 & 0.62 & 15 & 3 & 35.8 & 6.0 & 176 & 31 \\
\hline 12 & $9 a$ & $250-270$ & 0.37 & 0.23 & 0.01 & 18.05 & 2.25 & 78 & 11 & 36.1 & 3.7 & 156 & 19 \\
\hline 14 & $9 b$ & $250-270$ & 0.40 & 0.23 & 0.01 & 18.20 & 1.80 & 80 & 9 & 43.4 & 4.6 & 190 & 23 \\
\hline 17 & $11 a$ & $95-105$ & 0.80 & 0.31 & 0.02 & 5.60 & 1.00 & 18 & 3 & 71.8 & 11.3 & 228 & 39 \\
\hline 18 & 10 & $95-105$ & 0.57 & 0.27 & 0.02 & 9.45 & 0.95 & 30 & 4 & 41.8 & 4.7 & 134 & 17 \\
\hline 19 & $11 b$ & $250-270$ & 0.43 & 0.34 & 0.02 & 40.10 & 4.20 & 118 & 15 & 104.0 & 15.6 & 307 & 50 \\
\hline 20 & 12 & $350-370$ & 0.31 & 0.24 & 0.01 & 42.20 & 2.00 & 178 & 14 & 73.0 & 9.5 & 308 & 44 \\
\hline 21 & $13 a$ & $250-270$ & 0.41 & 0.48 & 0.04 & 45.00 & 5.00 & 93 & 13 & 112.1 & 14.8 & 232 & 35 \\
\hline 22 & $13 b$ & $350-370$ & 0.31 & 0.50 & 0.04 & & & & & 106.0 & 7.0 & 214 & 22 \\
\hline 23 & 14 & $115-125$ & 0.79 & 0.32 & 0.02 & 6.85 & 1.15 & 21 & 4 & 67.4 & 12.7 & 211 & 42 \\
\hline 24 & 15 & $180-200$ & 0.67 & 0.28 & 0.01 & & & & & 200.6 & 24.8 & 716 & 92 \\
\hline 25 & $16 a$ & $250-270$ & 0.42 & 0.28 & 0.02 & 35.65 & 3.65 & 129 & 16 & 94.0 & 11.2 & 341 & 46 \\
\hline 26 & $16 b$ & $350-370$ & 0.36 & 0.30 & 0.02 & 47.00 & 3.00 & 156 & 14 & 136.2 & 22.9 & 453 & 81 \\
\hline 29 & 18 & $250-280$ & 0.29 & 0.81 & 0.02 & 54.00 & 2.00 & 67 & 3 & 90.4 & 13.7 & 112 & 17 \\
\hline 30 & 19 & $250-275$ & 0.40 & 0.34 & 0.03 & 26.00 & 2.00 & 76 & 9 & 110.0 & 10.0 & 324 & 41 \\
\hline 32 & $20 a$ & $210 ?$ & 0.95 & 0.31 & 0.02 & 3.47 & 0.36 & 11 & 1 & 50.4 & 8.6 & 163 & 30 \\
\hline 33 & 21 & $250-275$ & 0.54 & 0.30 & 0.02 & 24.05 & 2.55 & 80 & 10 & 104.7 & 11.2 & 349 & 44 \\
\hline
\end{tabular}




\section{Highlights}

- The coastal sand dunes of Cooloola in south-east Queensland have been dated.

- Ten chronostratigraphic units have been identified.

- The oldest unit dates to 730 ka B.P.

- There is a relationship between the age of giant dune podzols and their biomass.

- The results are likely to be relevant to the adjacent Fraser Island sand mass. 


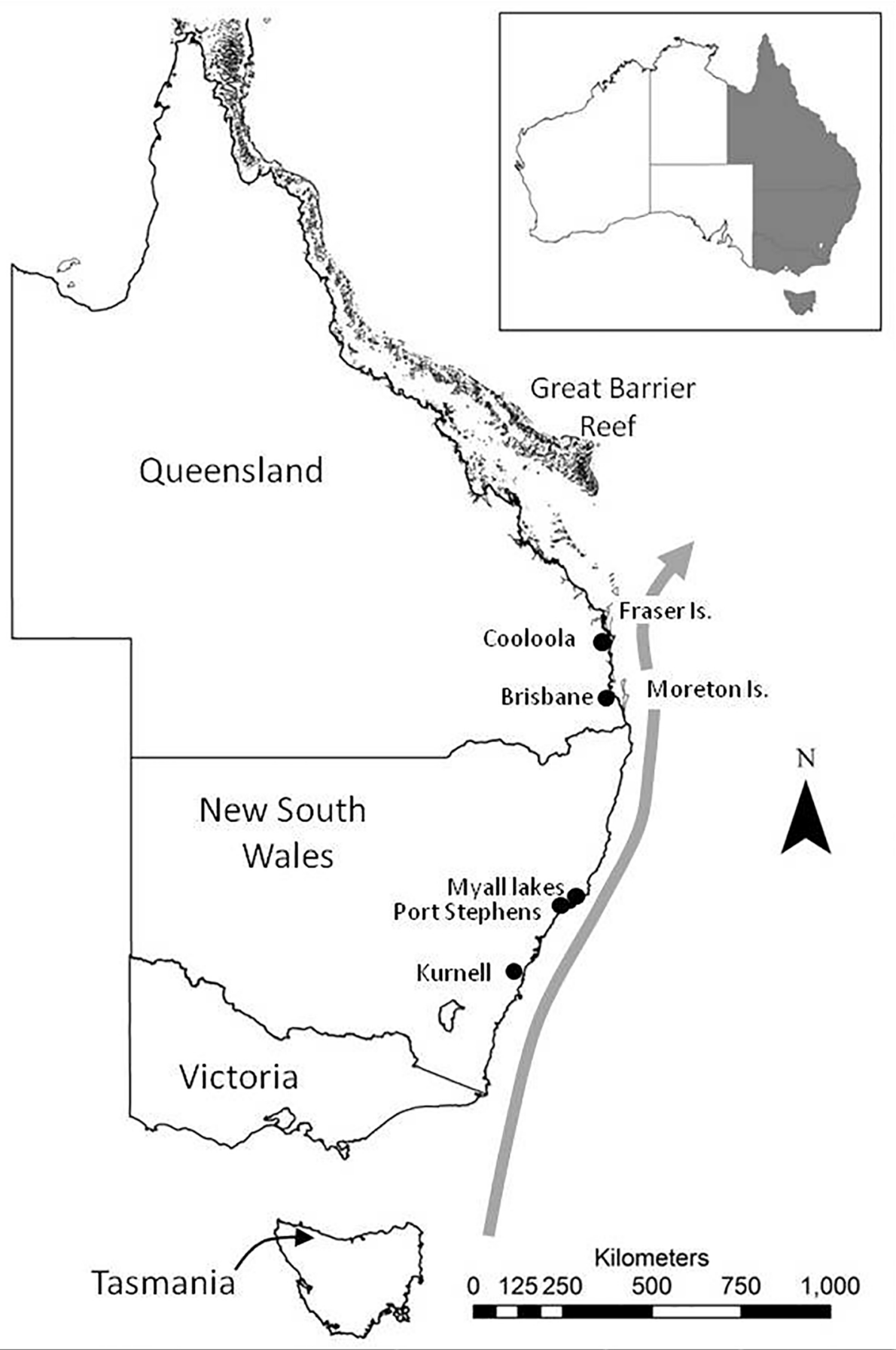

Figure 1 


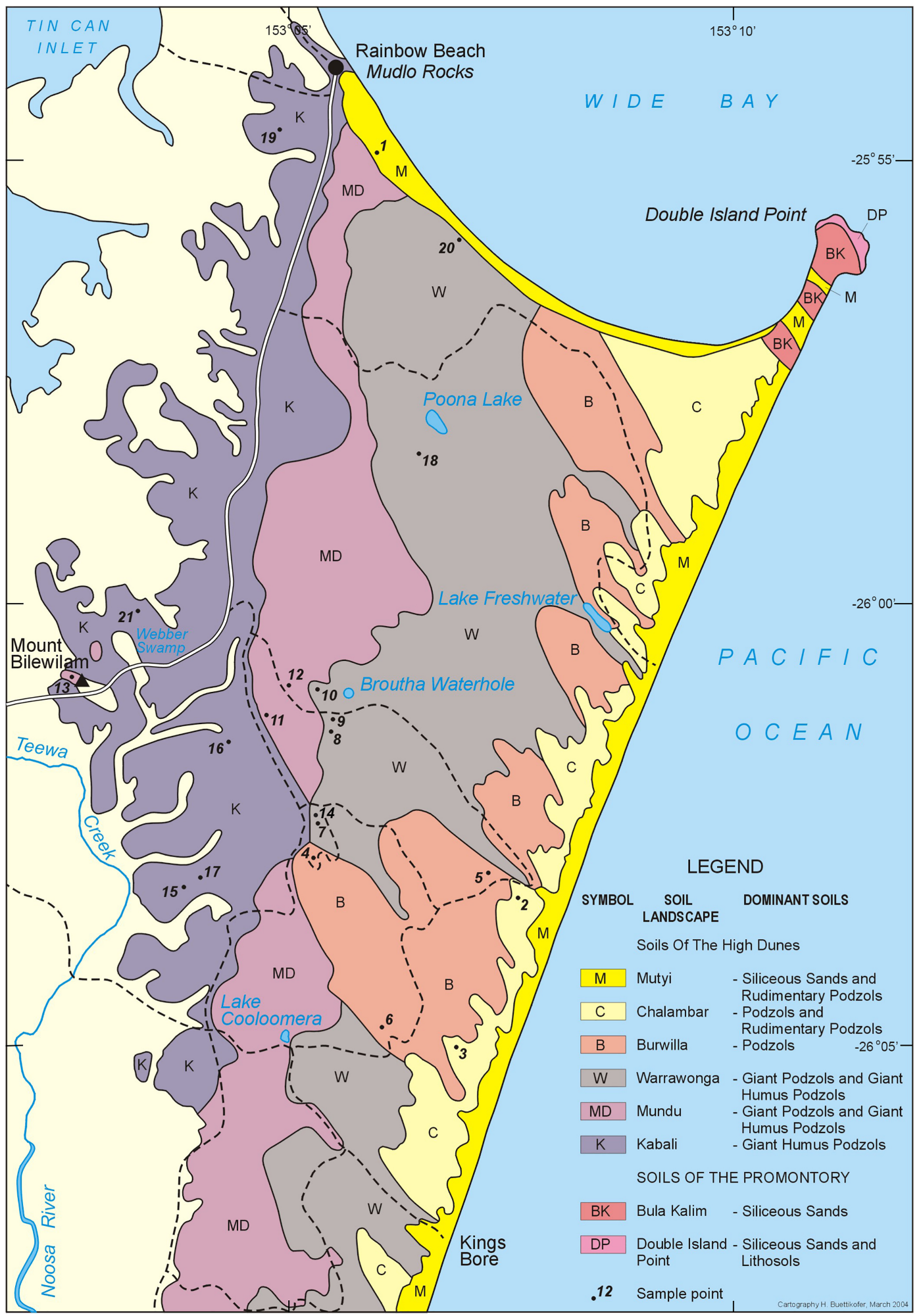


a

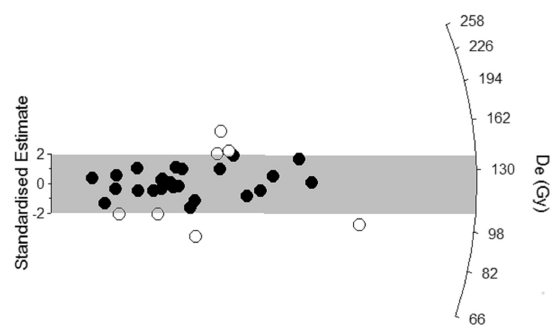

C
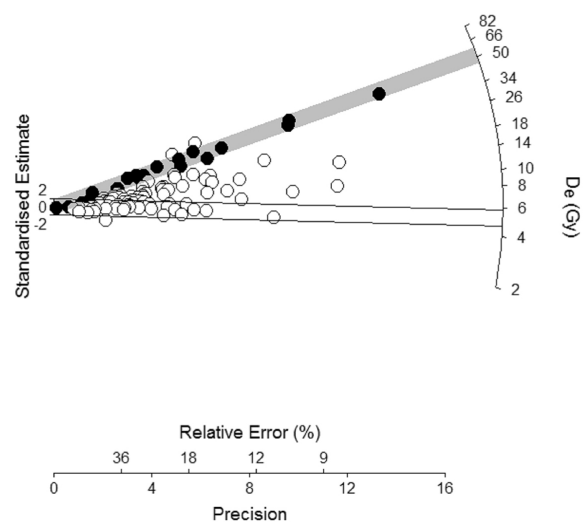
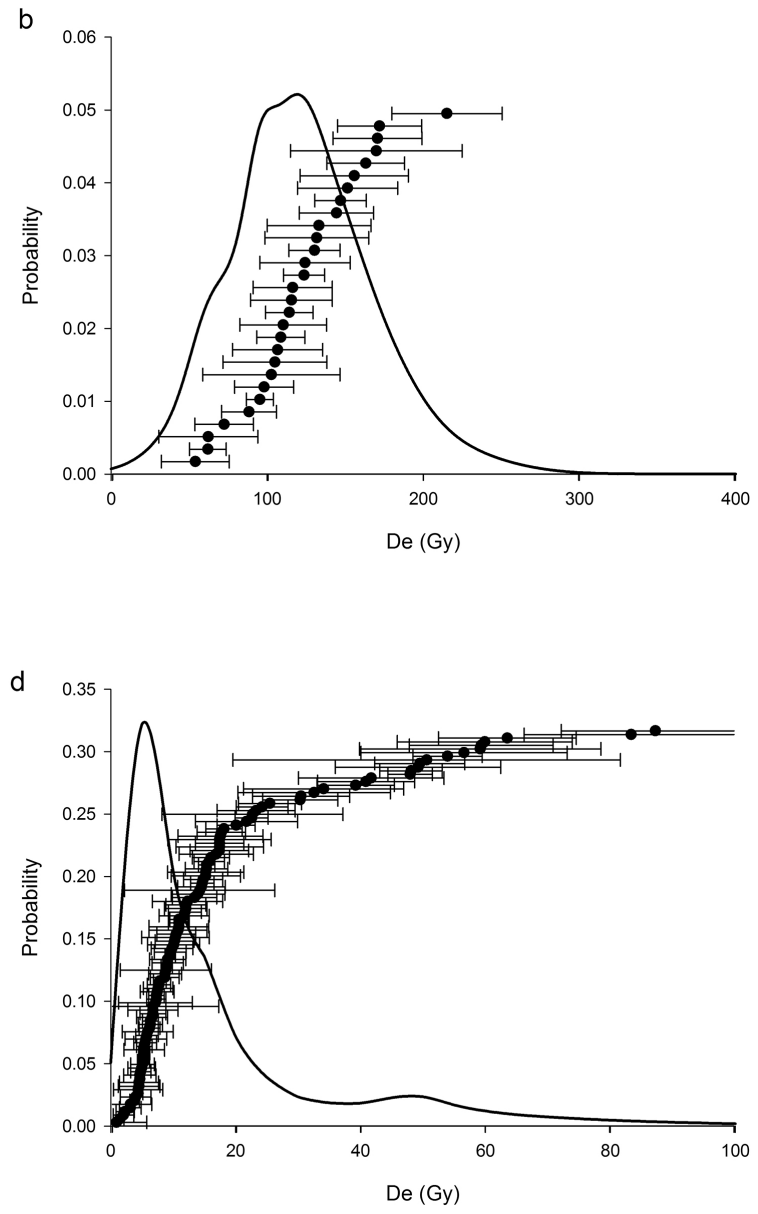

Figure 3 
(a)

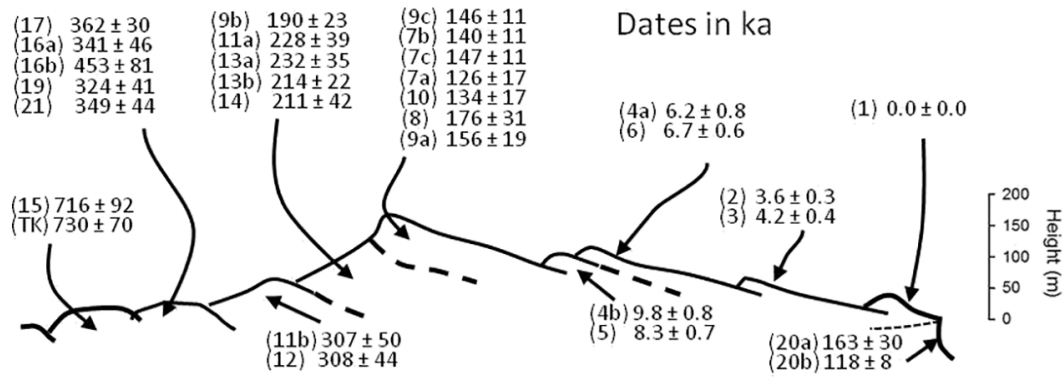

(b) DS 7(6b) 6a

54

3

2

1

$\left[\begin{array}{cc}60 & \\ -40 & \frac{\frac{1}{D}}{\frac{0}{0}} \\ -20 & \frac{3}{3} \\ -3\end{array}\right.$

(c)

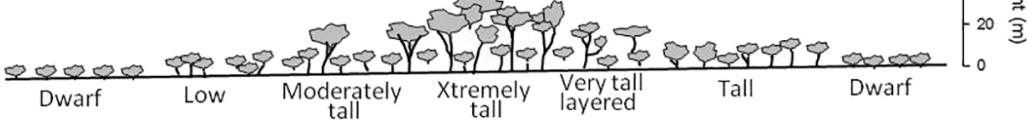
layered layered

(d)
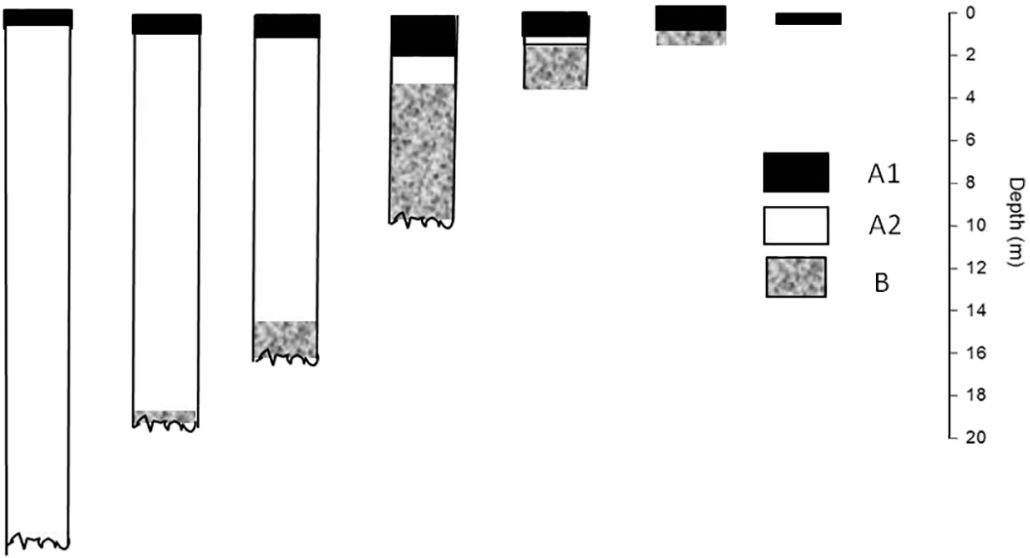

Figure 4 


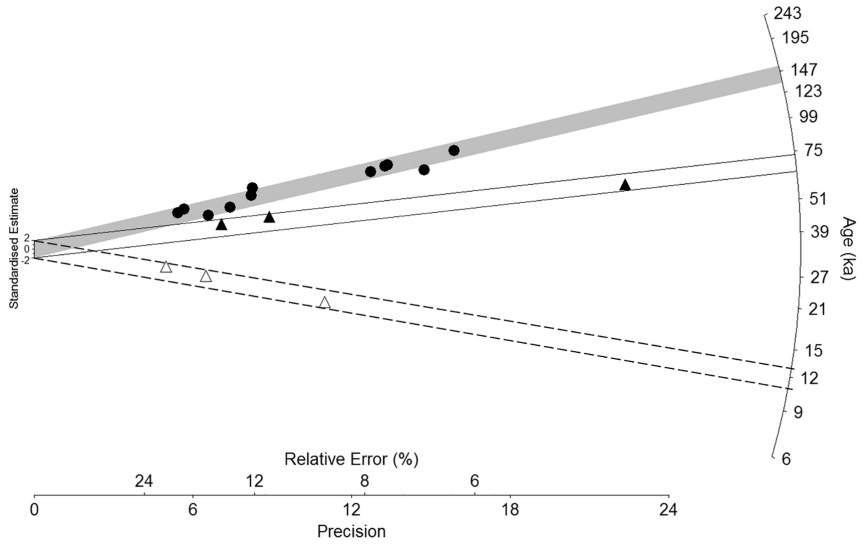

Figure 5 


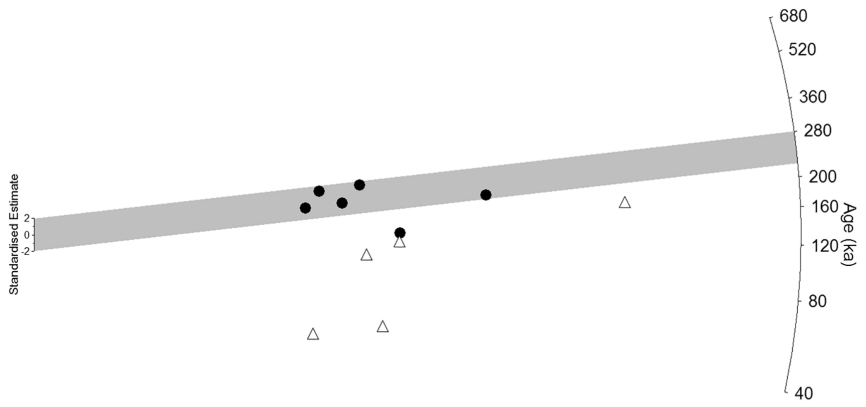

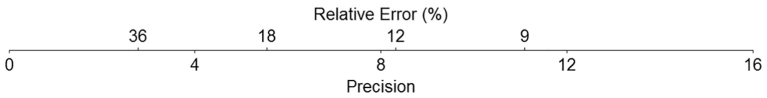

Figure 6 


\section{Accepted Manuscript}

Dating the Cooloola coastal dunes of South-Eastern Queensland, Australia

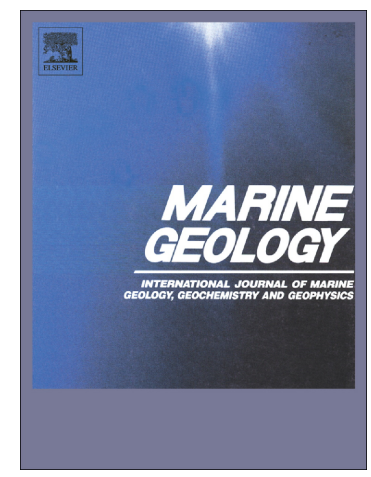

Joe Walker, Brian Lees, Jon Olley, Cliff Thompson

PII:

S0025-3227(17)30060-9

DOI: https://doi.org/10.1016/j.margeo.2017.12.010

Reference:

MARGO 5741

To appear in:

Marine Geology

Received date:

20 February 2017

Revised date:

16 May 2017

Accepted date:

29 December 2017

Please cite this article as: Joe Walker, Brian Lees, Jon Olley, Cliff Thompson, Dating the Cooloola coastal dunes of South-Eastern Queensland, Australia. The address for the corresponding author was captured as affiliation for all authors. Please check if appropriate. Margo(2017), https://doi.org/10.1016/j.margeo.2017.12.010

This is a PDF file of an unedited manuscript that has been accepted for publication. As a service to our customers we are providing this early version of the manuscript. The manuscript will undergo copyediting, typesetting, and review of the resulting proof before it is published in its final form. Please note that during the production process errors may be discovered which could affect the content, and all legal disclaimers that apply to the journal pertain. 